\title{
A Comparative Study of Political Discourse Features in English and Arabic
}

\author{
Asmaa Alduhaim ${ }^{1}$ \\ ${ }^{1}$ Department of English, American International College, Kuwait \\ Correspondence: Asmaa Alduhaim, Department of English, American International College, Kuwait. E-mail: \\ Asmaa.alduhaim@hotmail.co.uk
}

Received: July 27, 2019 Accepted: August 28, 2019 Online Published: October 13, 2019

doi:10.5539/ijel.v9n6p148 URL: https://doi.org/10.5539/ijel.v9n6p148

\begin{abstract}
This article is devoted to examine political discourse, in particular features of political speeches in English and Arabic Language. Political speeches are often shaped in a specific cultural and social context, using various linguistic features to persuade the public of the speaker's goals. The study has two aims: firstly, it intends to highlight the prominent features of political discourse in English and Arabic. For example, the use of metaphor and metonymy, pronouns, intertextuality, repetition, style and code-switching. In addition, the study examines the way these features were employed by the speakers. Secondly, the comparison across English and Arabic language establishes similarities and differences between the features of political discourse in English and Arabic, and understands to what extent are the features of political discourse universal and shared between languages, and to further examine in which ways they differ. Three main features were identified as shared between the two languages: pronouns, repetition, and intertextuality. Even though there were shared features, it emerges from the study that these features, as well as others, are employed differently based on the language convention and the culture it exists in.
\end{abstract}

Keywords: political speeches, linguistic features, Arab Spring, code-switching, intertextuality

\section{Political Discourse}

Political language is a language of power. It influences government policy and actions, identifies the dominant values of the moment, and wins votes. Likewise, it is a language that is capable of making war, establishing needs of its users at a particular time. Thus, it has a reputation for being flexible and ambiguous or, worse (Goshgarian, 2011, p. 426).

The urge to study political language dates back to the ancient Greek and Roman times, where it was referred to as the study of 'political sciences'. The field has witnessed continual development throughout the years. In the late seventeenth century, Thomas Hobbes introduced the modern political philosophy, which is now considered as the foundation of the political sciences discipline. In the following years, the notion of politics was linked to language and introduced by many pioneers as the study of 'political language' (Claeys, 2013, p. 776). Many scholars such as Lasswell (1949) argued that political language is seen as a language of influence since it aims at creating an impact on people. Therefore, Van Dijk claimed that the language of politics is indeed the language of power (2006, p. 362). According to Schaffner and Chilton (2002), in order to develop the field of political discourse, it is fundamental to study political discourse in depth since it is regarded as a complex human activity. Scholars further emphasise the importance of studying the political language in association with other important elements that may affect it, such as the culture and the audience.

Even though some scholars believe that it is notoriously difficult to define the notion of political discourse since it has a broad range of meanings, others argue that it has to do with anything said in public in relation to the political sphere. Feldman and Landtsheer (1998) claim that the most common term that refers to communication carried out in the political field is the term 'political discourse'. They define it as a way of using language in public communication that can be found in newspapers, television, radio stations, parliamentary debates and election speeches, etc. The language used in political discourse usually conveys power, as it aims to evoke public reaction (Landtsheer, 1998, p. 5). In this light, Chilton (2004) states that political discourse is perceived in two different ways; firstly, as a constant struggle between people who fight to obtain and assert power and those who stand up to it. Secondly, "as a cooperation, as the practices and institutions that a society has for resolving 
clashes of interest over money influence liberty and the like" (Chilton, 2004, p. 3).

\subsection{Political Speeches}

Political speeches as stated by Schaffner, share the same genre and characteristics as any political discourse, but may fall into a sub-genre. She further claims that regardless of the way they are all structured within a certain ideology and to address the public and persuade them with a given goal, political speeches often have different settings, for example when politicians address their nation in a televised recording (1996). Moreover, Schaffner emphasises that it is rather essential to create an analysis involving these following criteria: pragmatics, semantics, syntax and phonetics to examine political speeches, due to the communicative nature they have (Schaffner, 1996, p. 3). The significance of this sort of analysis is attributed to the rhetoric nature political speeches are known for. As Klein (1995) states that, the classic political rhetoric characteristics are in fact constitutive for the modern political communication, whereas Sauer (1996) presented a 'hybridisation' of the classic characteristics with the addition of the modern ones.

Political speeches are commonly characterised as a sophisticated, powerful and ambiguous type of language because they are rich in cultural and ideological elements. Similarly, to any other discipline, political language has many terms, jargons and slogans that may vary in meaning from one country to another; and is used to achieve specific political aims. In addition, a very crucial feature in political speeches is the tendency to use rhetorical language. It is described by Woodward and Denton Jr (2009) as the type of language that defends the attitudes, beliefs and values of the politician, whereas Beard (2000, p. 35) defines it as the art of persuasion through language in a written or a spoken form. According to David (2014) rhetoric language is conceived by many scholars as an approach of linguistic manipulation using persuasive language techniques that drive people to take certain political actions, and be persuaded by what politicians say. Thus, it is common among politicians and the writers of political speeches to utilise a range of powerful techniques such as allusion, metaphor and repetition in their speeches (Atkinson, 2005).

\section{Methodology}

This article combines a quantitative and qualitative approach to analyse prominent linguistic features of political discourse. The data is collected from two sources: (1) previous research conducted in the same field of political speeches analysis in English and Arabic languages throughout the past years, (2) my own research conducted in the past three years. The quantitative approach will be used to measure and analyse the number of times certain features were employed in a speech to highlight the significant of its usage. On the other hand, a quantitative approach provides grounds for an in-depth linguistic analysis of the prominent features of Arabic and English political discourse. These features are common linguistic tools that are employed by politicians in their speeches to influence the audience such as using pronouns, repetition or simply their own style. This article aims to establish the similarities and differences between the common linguistic features of political discourse in English and Arabic language.

\section{Features of English Political Discourse}

Many linguists (e.g., Edelman, 1977; Bolinger, 1980; Fairclough, 1989; Van Dijk, 1997, etc.) have examined the various techniques and types of languages politicians used to reinforce their ideologies in the masses and to attain certain objectives (David, 2014, p. 165). In political discourses, Van Dijk notes that there are crucial elements that help to draw and hold the attention of the audience, and persuade them of certain views (1997). Charteris-Black (2005) emphasises that successful politicians combine these elements effectively together to create a better impact and achieve their given goals. Below is an account of some of the prominent features of the political discourse in English and they are metaphors, metonymy, pronouns, intertextuality, repetition and style.

\subsection{Metaphor}

One of the most common linguistic tools found in the language of English political rhetoric is the constant use of metaphors. According to Kulo, metaphors are linguistic symbols that give concrete labels to abstract ideas (2009, p. 3). Metaphors are defined as the "figure of speech in which a word or phrase literally denoting one kind of object or idea is used in place of another to suggest a likeness or analogy between them" (Merriam-Webster, 2014).

According to Stepanyan, linguists consider metaphors as the most persuasive devise in political discourse, and the easiest way to reach peoples' consciousness (2015, p. 371). In a similar context, Mio notes, "metaphors allow the general public to grasp the meanings of political events and feel part of the process" (1997, pp. 117-118). This is especially true since using metaphors can make a speech more memorable, and evoke an emotional 
response (Penninck, 2014, p. 28). It can be argued that the significance of metaphor in politics lies in what it conceals. For instance, during the first Gulf War, countries were referred to as a person, each of which has hidden economic, religious and class divergences, they can be peaceful or aggressive (Lakoff, 1991, p. 3). Lakoff clarifies how this metaphor is used saying, "Iraq is villain, the US is hero, Kuwait is victim, the crime is kidnap and rape." (1991).

Many scholars believe that using metaphors in political discourse may project particular ideological and political beliefs in an indirect way (Beard, 2000). Hence, a politician's cultural background and religious beliefs may be reflected on the way they use language. Beard (2000) claims that there are two main sources of metaphors in politics and they are war and sport. He further explains that the usage of war or sport terminology to refer to a political event may reflect the idea of a fight where there is a winning party. An example of that is the announcement of the 1997 elections in the United Kingdom, which was referred to in newspapers as 'The Gloves Are Off", which clearly suggests a boxing match (Beard, 2000, p. 21).

\subsection{Metonymy}

Metonymy is another feature, which is often highlighted in political speeches. According to Beard (2000) metonymy is the act of replacing a word with a particular term or expression that may be related to it. Likewise, Lakoff and Johnson (2003, p. 35) illustrate that metonymy is produced when people understand one conceptual entity from another. They elaborate, the representation of a concept using a particular word is metonymy, and the word stands for the concept it expresses, thus metonymy can structure our language, thoughts, attitudes and actions (Lakoff \& Johnson, 2003, p. 39).

In political discourse, Wilson claims that metonymy helps "in arousing emotions and reinforcing particular perspectives, and results in eliciting absurd images which can then be employed for the purposes of ridiculing one's opponent" (1990, p. 104). Stepanyan also remarks that metonymy is closely linked to the speaker's image, since it is a unique rhetorical device that either increases or reduces the speaker's responsibility (2015, p. 378). It helps in perceiving the political images and simplify their meaning in a more focused manner (Stepanyan, 2015). As Beard writes, metonymy is widely used by politicians to simplify their utterances and make them more readable in newspapers (2000). An example of metonymy, which is used by both politicians and newspapers, is the usage of the term 'The White House' to simply refer to the President of the United States, his government and advisors (Beard, 2000, p. 19).

\subsection{Pronouns}

In political speeches, especially in English, speakers tend to use pronouns to emphasise certain points by replacing relevant nouns. Håkansson defines pronouns as "groups of words that are able to appear in the place of other words, most often nouns, other pronouns or noun phrase", and often used to avoid repetition (2012, p. 5). According to Collins, there are several types of pronouns, which are personal, reflexive, possessive, indefinite, demonstrative, reciprocal, relative and interrogative (1990, p. 28). Using any type of pronouns whether in utterance or writing aims to replace nouns to avoid monotony and boredom when constantly repeated (Sharndama, 2015, p. 21). Bramley, however, argues that the importance of pronouns goes beyond their linguistic function, and must be analysed in terms of their context, interaction and identity that they accomplish (2001, p. 13). Likewise, Sharndama (2015, p. 21) claims that sometimes using personal pronoun is a way of reflecting ideological references.

In political speeches, using pronouns can be quite manipulative, since it generates political stands (Chilton \& Schäffner, 2002, p. 30). Bello sees pronouns as linguistic tools used to relate to identities, group solidarity and most importantly to indirectly promote and sustain power $(2013$, p. 85). Gocheco also maintains that using the pronoun we is a strategy to express solidary, whereas using the pronoun $I$ is used to refer to the speaker's power (2012, p. 7). Irimiea believes that using pronouns in political speeches has a significant part of the message (2010, p. 4) She further argues that politicians use pronouns in their speeches to "foreground or to obscure responsibility and agency", since they usually represent political groups or parties (Irimiea, 2010). According to Fairclough, using the personal pronoun we by a leader it is usually to convey their humbleness $(1989$, p. 12). Bramley discusses pronouns in details, stating that the pronoun $I$ aims to present politicians as individuals and also to highlight their accomplishments, while using the pronoun we is used to invoke a group membership or a collective identity (2001, pp. 260-266). An example of using pronouns in political speeches is found in Churchill's speech during Second World War, when he constantly used the pronoun 'we' to refer to the entire country saying "We shall fight on the beach, we shall fight on the landing grounds" (Wilson, 1990, p. 47). 


\subsection{Intertextuality}

Intertextuality is among the common features of English political discourse, which is often associated with the speaker's knowledge (Beard, 2000). "Intertextuality is one of the important political communicative strategies ... which involves borrowing from previous texts or text-types in creating a new one" (Obeng, 2002, p. 9). It is recognised through the usage of different linguistic strategies such as allusion, quotation, and reference within the text to serve precise pragmatic functions (Genette, 1983).

An allusion, as described by Hebel (in Plett, 1991, p. 139), is an implicit, hidden or indirect reference or quotation that is used from another text, yet not literally said. Allusion is an effective linguistic tool that can be used to avoid direct threatening acts (David, 2014, p. 166). To demonstrate the use of allusion in English political discourse, David (2014) highlights how Ronald Reagan's borrowed an image from Magee's poem by John Gillespie to refer to the space shuttle explosion disaster in 1986, saying:

We will never forget them (the crew), nor the last time we saw them this morning, as they prepared for their journey and waved goodbye, and slipped the surely bonds of earth, to touch the face of God.

Quotation, on the other hand, is the reproduction of the same utterances said by another person that allocates a specific meaning (Hebel in Plett, 1991, p. 139). In addition, the use of references to clarify a point simply by referring to a certain entity (Plett, 1991). For instance, when the speaker uses a well-known historical or social event, without quoting them (Guerra, 2013, p. 60). In this regard, Van Dijk notes (1997), using references to information or knowledge, personal experience or observation has variable implications for the speaker's credibility. In fact, using quotation and references are never used arbitrarily but always with purpose, for instance President Obama was known to constantly quote Martin Luther King to reflect on his achievements and significance to Americans, and especially to African-Americans.

\subsection{Repetition}

Repetition is an effective tool often used by politicians. McArthur (1992, p. 861) suggests that repetition is understood by doing, saying or writing the same thing more than once. About using repetition in the political sphere, Obeng and Hartford rightly observe (2002, p. 85), the art of persuasion involves integrating many rhetorical features into the political discourse such as repetition, to enhance the perception of the discourse and attract the addressee. Charteris-Black writes, although repetition is a simple technique, it is indeed very effective and convey determination and strength of purpose (2014, p. 68). Likewise, David (2014, p. 167) stresses, repetition is one of the most effective rhetoric tools that manipulates the public to create an 'ideology' and persuade them to willingly accept it.

While Jones and Warening stress that repeating particular phrases may "contribute towards making the ideas contained in them seem "common sense" (1999, p. 39), Beard argues that repetition holds long speeches together, regardless to its simplicity (2000, p. 39). It can be a repetition of words, nouns, or even prepositions (Beard, 2000). Beard illustrates a certain type of repetition, three-part lists, which occurs when new ideas or pieces of information are presented in three parts as a pattern (2000, p. 38). A very famous example of the three-part motto in the political discourse is Churchill's 'blood, sweat, and tears' (Kulo, 2009, p. 7).

\subsection{Style}

Charteris-Black draws attention to another feature in political discourse, which distinguished each speaker by their 'style', which can differ from the mere analysis of 'delivery' by the way speakers always distinguish themselves with their unique style. This can be seen in the way they structure their speech, the way they use the settings to their advantage and the language they used. For instance, Martin Luther King's style is identified as 'African American liturgical', which involves the blending of cultural and historical experience (2013, p. 30). In his studies of political speeches, Charteris-Black introduces what he calls the 'conviction rhetoric'; which he defines as the way speakers portray their strong sense of purpose and self-belief by their choice of words, figure of speech, fluency and intensity of expression (Charteris-Black, 2011, p. 108). He (2011, p. 223) demonstrates this claiming that Tony Blair implemented his Christian belief of 'good' versus 'evil' in his speech about Saddam Hussain and his wrath about the catastrophes the regime caused, which is why it should be ended.

\section{Features of Arabic Political Discourse}

Political language and political speeches in particular, share similar features in different languages. As for Arabic language, politicians often employ linguistic features to make their speeches appealing and grab the attention. The following are the prominent features of political oratory in Arabic political discourse. 


\subsection{Pronouns}

Pronouns are considered as one of the most manipulative features in the political discourse in Arabic. Pronouns in Arabic are categorised as personal pronouns, demonstrative pronouns, and relative pronouns, and defined by by Ryding as "personal pronouns refer to persons or entities and stand on their own as substitutes for nouns or noun phrases" (2005, p. 298). This class has a wide range of role in Arabic language, and consists of three groups and they are subject, object and possessive pronouns. These personal pronouns demonstrate differences in gender, number, and person. The number of personal pronouns in Arabic includes 12 pronouns as opposed to English, which only has 8 pronouns (Ryding, 2005, p. 298). For example, using the pronoun 'you' in English has

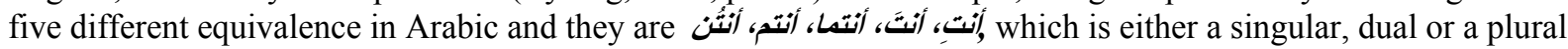
form (Shareef, 2016, p. 115)

Arabic pronouns are unique and different than those from any other language, because of the different forms it can occur in as singular words or as morphemes. Holes claims that in Arabic, pronouns can be suffixed to verbs, nouns, prepositions and may be the grammatical direct object (2004, p. 177).

According to El Samie (2016), the speaker's choice of pronouns may be part of the message they are sending, since pronouns can be used as a linguistic tool to enhance solidarity or power. He further claims that many leaders, as well as politicians tend to use the plural personal pronoun as a way of convincing protesters or the angry citizens with their intentional meanings, while at other times, it is used to emphasis solidarity with the protesters (El Samie, 2016). In a study about analysing two speeches of Mummar Algaddafi and Hosni Mubarak during the Arabic Spring, Alduhaim maintains that the presidents used first personal pronoun 'I' mainly to praise themselves, whereas the first personal plural pronoun 'we' indicates their intention of including themselves with the protesters and the people (2018, p. 54). For instance, Algaddafi used the pronoun ' $I$ ' for 105 in one of his speeches, and Mubarak used it for 84. On the other hand, Algaddafi used the pronoun 'we' for 135 times, whereas Mubarak used it 43 times (Alduhaim, 2018). Mubarak uses the pronoun 'I' twice as many times as he uses the pronoun "we". This indicates to some extent why a number of political analysts refer to the speech as a speech about Mubarak rather than about the uprising. This is contrary to Algaddafi, who uses the pronoun 'we' more often than he uses the pronoun 'I', which can be explained as his desire to engage with the tribes in Libya and to gain their support.

\subsection{Repetition}

One of the most common features in Arabic is the tendency to use repetition. Reynolds defines it as "multiple instances of an idea or word, and the greater the number of repetitions the more we notice it" $(1995, \mathrm{p}$. 185). He further claims that the more the word occurs in a text, the more attention it gets. Repetition in languages dates back to the pre-Islamic era, where it was seen as a "stylistic creativity in both speaking and writing" (Holes, 1995), and it is indeed highly approved in Arabic language, as it indicates how eloquent and creative the speaker is. In this regard, scholars such as Gass and New (1995) state that Arabic speakers use this feature to express how valuable something is to them; however, Israeli (1998) argues that non-native speakers of the language are struck by it, and see it as unnecessarily dwelling on one point and redundant.

According to Al-Khafaji repetition in Arabic language "can have didactic, playful, emotional, artistic, ritualistic, textual and rhetorical functions" $(2005$, p. 6). In a similar context, Koch maintains that repetition is a key to linguistic cohesion and rhythmic and rhetorical effectiveness in the Arabic language (1983, p. 48). Koch also notes that repetition exists on phonological, morphological, lexical, syntactic and semantic levels, it can be a repetition of form or a repetition of content (1983, p. 52). Beeston (1970) believes that Arabic speakers usually avoid repetition by using both synonyms and near-synonyms, which would reflect the knowledge of the author/speaker. "Arabs delight in playing with words... and in their tendency to fit the thought to the word or the combination of words, rather than the word to the thought" (Shouby, 1951, p. 293). Arabs are fond of using more than one term to emphasis one particular idea, which can evoke an emotional response, thus, "synonymous pairs are considered a form of repetition, which is a broadly used stylistic device in MSA" (El-Farahaty, 2014, p. 43).

Repetition is considered as a very effective linguistic tool and often used in political speeches. Arabic language and political discourse in particular have been notoriously known for its use of repetition. According to Johnstone, the reason is that repetition is a purposeful device that can be used to persuade people and create an emotional impact (Johnstone, 1994). Johnstone (1991) further claims that Arab audience are persuaded by repetition and the display of strong emotions during arguments. To Hoey (1991), repetition in the Arabic political discourse should not be considered repetition but rather a replacement of new terms for the same information meant simply to allure the audience. Mazraani (1997, p. 206) justifies using repetition in political speeches as follows: 
Repetition of an item highlights it, helps its comprehension by providing greater textual redundancy and less dense discourse. Rhythmically, repetition provides a musical aspect to language and may create a rhetorical crescendo and captures audience attention. Patented repetition is a technique of persuasion.

Shunnaq lists three types of repetition in political speeches: repetition embedded in language and used normally by the user, functional and communicative repetition that serves a purpose, and unnecessary repetition such as 'tautologies' or 'pleonasms', which is known in Arabic as (1992, p. 32). In an attempt to investigate this phenomenon, Shunnaq conducted a study, which analyses the features of Arabic political discourse in Gamal Abdul Nasser's political speeches (2000). In his study, Shunnaq reveals that the amount of repetition used in the speech had a parallel structure and served the purpose of emphasis. For example, the parallelism and constant use of the phrase الأخوة المواطنون 'Dear fellow citizens' aimed to reinforce the meaning and arouse emotions (2000, p. 215). This has been observed in Hosni Mubarak's speeches during the uprising in 2011, where he repeated this particular phrase for nine times for similar reasons.

Despite the fact that repetition might reflect the speaker's intention of emphasising a point and attracting people's attention, it can also be a sign of the speaker's competence to impose a particular idea over the addressees. Consider the example below.

$$
\text { شبر شبر، بيت بيت، دار دار، زنقه زنقه، فرد فرد }
$$

'Span by span, house by house, room by room, alley by alley, person by person'

Algaddafi's uses a repetitive pattern by repeating different synonyms in a particular order, which aims to threaten the protesters by looking for them all over Libya. He starts by stating that he would start his search in each span in Libya, and then gradually enhances the search to include each house, and each room in the house, each alley in Libya and finally each person. Not to mention that Algaddafi's usage of the same lexical item twice aims to enforce his threats and his obligation to follow through with them.

\subsection{Religious and Ideological References}

Another element that distinguishes Arabic political speeches is the reflection of religious and ideological beliefs in the political discourse. According to Welch, Cullbert, and Cull (2003, p. 342), many scholars believe that it is by far the most important feature that most politicians use to manipulate the public, and religion was always used as propaganda to achieve hidden political purposes, and many political speeches use religious references or quotations (Welch, Cullbert, \& Cull, 2003). They add:

Religion is often used in propaganda because, once established, it rules out all other arguments, such as human rights, vested interests, political privileges, or property rights. It is the ultimate instrument of political power.

According to Wodak, "the power of persuasion can be displayed by different traits. Part of these traits is the display of belief, which can be considered as a necessary ingredient for the staging of politics" (2009, p. 8). Barakat (1993) also notes, when politicians use religion to enforce their point of view or to emphasise its importance, they are completely aware of the effect that religion has on the audience. It is a significant device, which targets the audience's moral approval and raise the desire to obey religion (Barakat, 1993).

Religion has always been intertwined with the political platform in the whole world and in the Arab world in particular. As Abdul-Latif (2011, p. 50) writes, "religion and politics have a complicated relationship in the Arab world". In this context, Kammoun stresses that politics and religion have an old complex relationship in the Arab world (2015, p. 130). She observes, religious expressions are part of the Arabic discourse due to the fact that Arabic is the language of the Quran (Kammoun, 2015).

In Arabic political discourse, it is very common, if not even a norm, to start political speeches, debates, and even parliamentary sessions with a Qur'anic verse or religious terminology. Roy remarks, "a political speech will begin with a Qur'anic hook, a few verses meant not to explain, but to anchor the speech in transcendency..." (1994, p. 103). This phenomenon was deeply analysed by Dähne (2001, p. 11), who writes, political speeches generally adopt Qur'anic vocabulary for aesthetic reasons and to sacralise the speech; furthermore, it helps strengthen the speaker's position and protect them against disapproval and surely for its rather emotional effect. Dähne (2001) explains the way the Qur'anic equivalence is always intertwined within speeches due to the widespread knowledge of the Qur'an among the Arab speaking countries (Dähne, 2001). In the same vein, Abdul-Latif justifies the use of religious expressions as a persuasive tool in political speeches, because religious discourse is 'immune' to any dissent or resistance (2011, p. 57). He maintains that Qur'anic phrases often lead to a fast consensus because of the infallibility of the sources, and integrating religious discourse results in creating a more powerful political discourse $(2015$, p. 180). 
Religious and ideological references are not only reflected by using Qur'anic phrases, but also by using words that stem from a particular ideology. According to Israeli (1998), words like 'Zionism, jihad, Baath, and martyr' carry an Islamic connotation and may reflect the speaker's attitude and beliefs. Israeli (1998) illustrates this further with an example of Anwar Sadat's speeches; claiming that Sadat's deliberate usage of the word Allah /God in almost all his speeches created a link between him and people. One of his famous phrases is "You are, after Allah, my source of encouragement, stamina, and inspiration" (Israeli, 1985, p. 26). Sadat's clever attempt to link people to Allah/God is mainly to indicate their importance and his utmost belief in them as a source of inspiration and power to him (Israeli, 1985). This can surely play a major role in persuading the audience and acquiring their approval. Abdul-Latif also conducted a similar study about Sadat (2011, p. 58) saying that Sadat integrated religion as an important argumentative device in his speeches. He was known to use phrases and terminologies with religious references such as the phrase بشيئة الرب 'God's choice', and إن شاء الله 'God's will' (Abdul-Latif, 2011, p. 58). Sadat often conveys his speeches with a religious perspective by drawing on a religious sermon genre, as he often quotes verses from the Qur'an (Abdul-Latif, 2011, pp. 60-64), for example, in his speech on February 5, 1977, he said:

$$
\text { وبأقول لثعبنا زي ربنا سبحانه وتعالي ما خاطبنا وقال: لا تحزنوا وأنتم الأعلون }
$$

And I say to our people as our Lord the exalted and high spoke to us and "Do not be sad, ye are the superiors.

In a recent study, Abu-Ain examines the religious references in King Hussein's political speeches emphasising how his speeches are intertextually linked to Qur'an (2014, p. 262). Abu- Ain states, "the intertextual bond with Qur'an, Hadith and Islamic history is not restricted to King Husseine's political speeches ... but it is a distinguishing trait of Arabic political discourse..." (Abu-Ain, 2014, p. 263). Consider the following example, which elaborates how King Husseine's used religious references in his speech on February 7, 1999 (Abu-Ain, 2014, p. 196)

$$
\text { الحياة و الموت بيد الله سبحانه وإذا جاء أجلهم لا يستأخرون ساعةً ولا يستقدمون }
$$

Life and death are in the hand of God, and when the time comes, none shall delay it nor advance it even by an hour.

Abu-Ain explains that the King delivered this speech when he knew he was ill and dying, hence, it is not surprising that he has used this Qur'anic verse (2014). This is due to the significance of the verse and what it refers to of how death cannot be postponed.

\subsection{Code-Switching}

Code-switching is a linguistic phenomenon that occurs when the speaker alternate between one language to another, or within language varieties (Gumperz, 1982). According to Gumperz code-switching is "the juxtaposition within the same speech exchange of passages of speech belonging to two different grammatical systems of subsystems" (1982, p. 59). Myers-Scotton $(1988,2006)$ defines it as using different styles of register, whether more or less, and it can be seen in choosing certain lexical items, the choice of changing from one language into another, or sometimes the change of dialects within the same language. According to Gumperz, there are many benefits of code-switching and it is in fact considered a discourse strategy used by many to serve certain purposes (1982). Gumerz (1982, p. 75) writes:

it can serve many functions such as quoting, specifying the addressee, interjecting, reiterating qualifying the message, while the subjective is to show solidary with the interlocutor or establishing some kind of distance, or implying the speaker's involvement with his discourse and the audience.

Bassiouney (2009) asserts that code-switching is common in Arabic language when speakers switch between modern standard Arabic and the different Arabic dialects. The process and the relation between changing codes is rather complicated and not simply a lexical choice. She (2009) further illustrates that there is a tendency to use this strategy in political speeches for persuasive purposes. Therefore, it is not surprising to see Arab leaders and politicians deliberately switching to the colloquial Arabic when addressing the nation. For instance, Algaddafi chose to deliver his speech in a Libyan dialect for similar purposes. His speech was in colloquial Arabic mainly to attach himself to Libyans and appeal to the Libyan tribes.

In this regard, Mazraani (1997, p. 105) claims that code-switching is a common style that is used to gain emotional support from the audience, create a sense of solidarity and intimacy and signal unity. According to Mazraani (1997), on using code-switching in political speeches, politicians would start their communication by appealing to the emotions of the audience and then establish authority by reverting to Standard Arabic. This mechanism of switching from a formal language into the public's dialect would increase their attention and 
understanding and cause them to feel a connection with the speaker (Mazraani, 1997).

A very recent example is Zine El Abidine Ben Ali's creative linguistic manipulation in his last speech as the Tunisian president during the Arab Spring in 2011(Lahlali, 2011). Lahlali argues, although Ben Ali started his speech by announcing that he would talk to the nation and the world in his Tunisian dialect, there were certain occasions where he switched from the Tunisian dialect into MSA, for instance (2011, pp. 3-11):

$$
\text { العنف ما هوش متاعنا ولا هو من سلوكنا }
$$

Violence has never been part of our custom or part of our behaviour.

$$
\text { حتى نفرق بين هذه العصابات و المجموعات من المنحرفين }
$$

Until we isolate these gangs and groups of delinquents...

As illustrated above, Ben Ali's switch in discourse is his attempt to appear more patriotic, conveying that he belongs to the nation and there are no social differences between him and the public. Lahlali claims that he was "trying to appeal to a wider section of the Tunisian society, especially those less educated people who couldn't easily follow his speech in MSA" (2011, p. 11).

\subsection{Cultural References: The Use of Poetry}

In order for politicians to reflect unity and a sense of belonging to the public, they often employ cultural-specific expressions or cultural tools within their speeches. According to Abu Hatab (2005), Arabic political speeches incorporate cultural items that are related to religion, folklore, and other Arabic cultural features. Among the popular cultural tools in Arabic language is poetry. It plays an important role in the Arabic language; in fact, it was always associated with politics. "Arabs have always prided themselves on their poetry, which they regard as their greatest and most congenial mode of literary expression" (Badawī, 1975, p. 56).

In this context, Alshaer (2014) writes there is a fundamental connection between poetry in politics that reflects the holistic character of the Arab culture and the ancient embodiment of poetry in the socio-political life of Arabs. He (Alshaer, 2014) further explains that poetry has always been a medium of expressing tension and aspirations and mobilizing in the region. "poetry has always been a privileged means of expression in Arabic... and politics is no exception" (Alshaer, 2014). This has also been highlighted by Moreh (1976, p. 217), who clarifies how poetry is like an instrument of expression for nationalist, socialist, and communist movement in the Arab world.

During the Arab Spring, poetry was considered one of the tools used by protesters in 2011 to establish their stance. Colla (2011) illustrates how famous poets and activists composed clever-couplet-slogans, creating a unique style of poetry in Egypt. He writes (2011), hundreds of poems are composed in colloquial Arabic and extremely catchy and easy to sing that aims to be chronicles of the current situation in Egypt. Sanders and Visona writes (2012, p. 214):

During the eighteen days leading to Mubarak's resignation, the poet rose to the foreground of the social landscape. This became evident in the multitude of chants, songs, and pomes erupting in Tahrir Square as well as throughout Egypt.

Ahmed Mekky was among the poets who wrote about the Egyptian uprising in 2011. Mekky, who is an actor, director, author and rapper chose writing a poem and transferring it into a song as his medium during the uprising (Sanders \& Visona, 2012, p. 234). His popular poem entitled 25 يناير 'January 25' showcases the revolution and the youth achievements. Table 1 shows lines of his poem.

Table 1. Lines from Ahmed Mekky’s poem entitled 25 يناير 'January 25'

\begin{tabular}{lc}
\hline Translation & Arabic Text \\
\hline The dignity of the Egyptian is worth much to him... He wants it & كرامة المصري تسوا عنده كتير... نفسه يرجع كرامته و الفساد يطير أنادر يوم 25 \\
back, and for corruption to fly away... & \\
January 25... & \\
Anniversary for the greatest Egyptian revolution of all time ... & \\
(Sanders \& Visona writes, 2012, p. 234) & \\
\hline
\end{tabular}

\section{Conclusion}

This article presents relevant findings about commonalities and differences between the characteristics of political discourse in Arabic and English. It further aims to highlight how the features of political discourse are 
often universal and shared between languages. The brief overview of these features in English and Arabic shows that they have some features in common, such as intertextuality, repetition and the use of pronouns. Nonetheless, in each language these features are employed rather differently, depending on linguistic and cultural conventions. For instance, the use of intertextuality differs in the way it is used in Arabic and English. Intertextuality is applied in English in the form of quotations, allusions and cultural references to other texts, whereas in Arabic intertextuality is widely used to bring cultural, religious and poetic references. The use of cultural references differs in English and in Arabic, since the latter is known for quoting poetry and Qur'anic verses, whereas in English cultural references include quotations by famous politicians such as Winston Churchill, for instance. One must argue that the use of religious references is more common in contemporary Arabic than in contemporary English, as Western democracies are multicultural and largely secular (Hurd, 2009).

Repetition, on the other hand, is a common rhetorical tool that is used differently in English and Arabic political discourse. In English, repetition is used through the 'three-list' repetition, which aims to evoke emotions and create a slogan that people will remember; whereas in Arabic, it is realised through the use of synonyms and near-synonyms, and sometimes the repetition of ideas, which shows the speaker's fluency and the richness of their speech.

In regards to the use of pronouns, it has been widely suggested that particular pronouns can define solidarity, while others can indicate arrogance and self-praise; both varieties are used equally in both languages. For example, the pronoun ' $w e$ ' is used to demonstrate solidarity, whereas the pronoun 'I' denote the speaker's self-praise.

However, I suggest that the most noteworthy feature that distinguishes Arabic from English is 'code-switching', or using MSA versus colloquial Arabic, especially since using the latter carries particular significance in the region. This feature is therefore important as it portrays the speaker's attitude and sends a message of unity and belonging to the public. While using MSA can be seen as a way of detaching oneself from the public, and appearing in an official way, using Colloquial Arabic can influence how the speech is perceived by the public. To some extent, this can be seen in English, as the style and register through which speakers express themselves. Donald Trump's use of language, for example, is hugely different from that of other politicians; he uses lower colloquial registers and even demotic language in his speeches. From an analytical point of view, it is obvious through this examination that politicians often use similar features that are universal in political discourse, but are employed differently based on the language and culture they are from.

\section{References}

Abdul-Latif, E. (2011). Interdiscursivity between Political and Religious Discourses in a Speech by Sadat: Combining CDA and Addressee Rhetoric. Journal of Language and Politics, 10(1), 50-67. https://doi.org/10.1075/jlp.10.1.03abd

Abdul-Latif, E. (2015). Al-'st'ārh Bwşfhā 'qnā'ā: Drāsh fì khțāb Al-'bwī-a Al-msthdth-a fì Al-'ālm Al-'rbì [Persuasion in Metaphor: A study of the New Fatherhood Approach in Speeches in the Arab World]. Doha: Qatar University.

Abu-Ain, S. (2014). Equivalence in Translating Metaphors and Idioms in King Hussein's Political Speeches. Doctoral dissertation, University of Leeds.

Abu Hatab, W. (2005). Quality of Translation and Challenges of the New Millennium: Facts and Ethics. Jordan: Zarka University.

Alduhaim, A. (2018). Multimodal translation analysis: Arab Spring speeches in Arabic and English. Doctoral dissertation, University of Birmingham.

Al-Khafaji, R. (2005). Variation and Recurrence in the Lexical Chains of Arabic and English Texts. In De Gruyter (Ed.), Poznan Studies in Contemporary Linguistics, 40, 5-25.

Alshaer, A. (2014). Poetry and Politics in the Modern Arab world. London: Hurst and Columbia University Press.

Atkinson, M. (2005). Lend Me Your Ears: All You Need to Know about Making Speeches and Presentations. Oxford: Oxford University Press.

Badawī, M. M. (1975). A Critical Introduction to Modern Arabic Poetry. Cambridge: Cambridge University Press. https://doi.org/10.1017/CBO9780511554124

Barakat, H. (1993). The Arab World: Society, Culture and State. Los Angeles, London: University of California Press. 
Bassiouney, R. (2009). Arabic Sociolinguistics. Edinburgh: Edinburgh University Press. https://doi.org/10.3366/edinburgh/9780748623730.001.0001

Beard, A. (2000). The Language of Politics. London: Routledge.

Beeston, A. (1951). The Arabic Language Today. London: Hutchinson University Library.

Bello, U. (2013). “If I Could Make It, You Too Can Make It!” Personal Pronouns in Political Discourse: A CDA of President Jonathan's Presidential Declaration Speech. International Journal of English Linguistics, 3(6), 84. https://doi.org/10.5539/ijel.v3n6p84

Bolinger, D. (1980). The Loaded Weapon: The Use and Abuse of Language Today. London and New York: Longman.

Bonner, A. (2012). Speaking, Writing and Presenting In SOCKOS. Canada: Sextant Publishing.

Bramley, R. N. (2001). Pronouns of Politics: The Use of Pronouns in the Construction of 'self' and 'other' in Political Interviews. Australia: Australian National University.

Busch, B. (2009). Media Politics and Discourse Interactions. In J. Mey (Ed.), Concise Encyclopedia of Pragmatics (2nd ed.). Elsevier Science.

Charteris-Black, J. (2005). Politicians and Rhetoric: The Persuasive Power of Metaphor. Basingstoke: Palgrave-Macmillan. https://doi.org/10.1057/9780230501706

Charteris-Black, J. (2013). Analysing Political Speeches: Rhetoric, Discourse and Metaphor. Basingstoke: Palgrave Macmillan. https://doi.org/10.1007/978-1-137-36833-1

Chilton, P., \& Schaffner, C. (2002). Politics as Talk and Text: Analytical Approaches to Political Discourse. Amsterdam and Philadelphia: John Benjamins Publishing Company. https://doi.org/10.1075/dapsac.4

Chilton, P. (2004). Analysing Political Discourse: Theory and Practice. London: Routledge. https://doi.org/10.4324/9780203561218

Claeys, G. (2013). Encyclopaedia of Modern Political Thought (set). Washington: CQ Press. https://doi.org/10.4135/9781452234168

Colla, E. (2011). The Poetry of Revolt. In B. Haddad, R. Bsheer \& Z. Abu-Rish (Eds.), Dawn of the Arab Uprisings: End of an Old Order. London: Pluto Press.

Collins, C. (1990). English Grammar. London. Collins ELT.

Cull, N., Culbert, D., \& Welch, D. (2003). Propaganda and Mass Persuasion: A Historical Encyclopaedia, 1500 to the present. ABC-CLIO.

Dähne, S. (2001). Qur'anic Wording in Political Speeches in Classical Arabic Literature1. Journal of Qur'anic Studies, 3(2), 1-13. https://doi.org/10.3366/jqs.2001.3.2.1

David, M. (2014). Language, Power and Manipulation: The Use of Rhetoric in Maintaining Political Influence. Frontiers of Language and Teaching, 5(1), 164-170.

Edelman, M. (1977). Political Language: Words that Succeed and Policies that Fail. New York: Elsevier.

El-Farahaty, H. (2015). Arabic-English-Arabic Legal Translation. London and New York: Routledge. https://doi.org/10.4324/9781315745893

El Samie, Y. (2016). The Revolutionary Arab World from a Corpus-Pragmatic Perspective: Tunisia, Egypt and Libya. North Carolina: Lulu. com.

Fairclough, N. (1989). Language and Power. London: Longman.

Gass, S., \& Neu, J. (2006). Speech Acts Across Cultures: Challenges to Communication in a Second Language (Vol. 11). Berlin: Walter de Gruyter. https://doi.org/10.1515/9783110219289

Genette, G. (1983). Narrative Discourse: An Essay in Method. New York: Cornell University Press.

Gocheco, P. (2012). Pronominal Choice: A Reflection of Culture and Persuasion in Philippine Political Campaign Discourse. Philippine ESL Journal, 8, 4-25.

Goshgarian, G. (2011). Exploring Language (14th ed.). London: Longman Publishing Group.

Guerra, C. H. (2013). Textual, Intertextual and Rhetorical Features in Political Discourse: The Case of President Obama in Europe. Revista De Lingüistica $Y$ Lenguas Aplicadas, 8, 59-65. https://doi.org/10.4995/rlyla.2013.1175 
Gumperz, J. (1982). Discourse Strategies (Vol. 1). Cambridge: Cambridge University Press. https://doi.org/10.1017/CBO9780511611834

Håkansson, J. (2012). The Use of Personal Pronouns in Political Speeches: A Comparative Study of the Pronominal Choices of Two American Presidents. Sweden: Linnaeus University. Retrieved March 22, 2015, from http://www.diva-portal.org/smash/get/diva2:531167/fulltext01.pdf

Hoey, M. (1991). Patterns of Lexis in Text. Oxford: Oxford University Press.

Holes, C. (1995). The Structure and Function of Parallelism and Repetition in Spoken Arabic: A Sociolinguistic Study. Journal of Semitic studies, 40(1), 57. https://doi.org/10.1093/jss/XL.1.57

Holes, C. (2004). Modern Arabic: Structures, Functions, and Varieties. Washington: Georgetown University Press.

Hurd, E. (2009). The Politics of Secularism in International Relations. New Jersey: Princeton University Press. https://doi.org/10.1515/9781400828012

Irimiea, S. (2010). A Rhetorical and Comparative Study of The Victory Speeches of Barack Obama and Mircea Geoana. The Journal of Linguistic and Intercultural Education, 3, 41.

Israeli, R. (1985). Man of Defiance: A political Biography of Anwar Sadat. New York: Barnes \& Noble Imports.

Israeli, R. (1998). The Cases of Sadat and Arafat. In O. Feldman \& C. Landtsheer (Eds.), Politically Speaking: A Worldwide Examination of Language Used in the Public Sphere (p. 19). New York: Barnes \& Noble Imports.

Jarraya, S. (2013). Persuasion in Political Discourse: Tunisian President Ben Ali's Last Speech as a Case Study. New York: Syracuse University.

Johnstone, B. (1991). Repetition in Arabic Discourse: Paradigms, Syntagms and the Ecology of Language (Vol. 18). Amsterdam: John Benjamins Publishing. https://doi.org/10.1075/pbns. 18

Johnstone, B. (1994). Repetition in Discourse: Interdisciplinary Perspectives (Vol. 1). New York: Ablex Publishing Corporation.

Jones, J., \& Warening, S. (1999). Language and Politics. In L. Thomas (Ed.), Language, Society and Power (pp. 31-47). London: Routledge.

Kammoun, R. (2015). Gender and Political Discourse in Tunisia. In J. Wilson \& D. Boxer (Eds.), Discourse, Politics and Women as Global Leaders, 63, 121. https://doi.org/10.1075/dapsac.63.06kam

Klein, J. (1995) Politische Rhetorik. Eine Theorieskizze in Rhetorik-kritischer Absicht mit Analysen zu Reden van Goebbels, Herzog und Kohl. Sprache und Literatur in Wissenschaft und Unterricht, 75/76, 62-99.

Koch, B. J. (1983). Presentation as Proof: The Language of Arabic Rhetoric. Anthropological Linguistics, 47-60.

Kulo, L. (2009). Linguistic Features in Political Speeches: How Language Can be used to Impose Certain Moral or Ethical Values on People. Bachelor Thesis. Sweden: Lulea University of Technology. Retrieved May 15, 2015, from http://www.divaportal.org/smash/get/diva2:1028973/FULLTEXT01.pdf

Lahlali, M. (2011). The Arab Spring and the Discourse of Desperation: Shifting from an Authoritarian Discourse into a "Democratic" One. Journal of Arab Media and Society, 13. https://doi.org/10.3366/edinburgh/9780748639090.003.0005

Lakoff, G. (1991). Metaphor in Politics: An Open Letter to the Internet by George Lakoff. Retrieved May 13, 2015, from http://philosophy.uoregon.edu/metaphor/lakoff-1.htm

Lakoff, G., \& Johnson, M. (2003). Metaphors We Live By. Chicago: University of Chicago press. https://doi.org/10.7208/chicago/9780226470993.001.0001

Lasswell, H. (1949). Style in the Language of Politics. In N. Lasswell (Ed.), Language of Politics: Studies in Quantitative Semantics (pp. 20-39). New York: George W. Stewart.

Mazraani, N. (1997). Aspects of Language Variation in Arabic Political Speech-Making. London: Routledge.

McArthur, T. (1992). The Oxford Companion to the English Language. Oxford: Oxford University Press.

Mio, J. (1997). Metaphor and Politics. Metaphor and Symbol, 12(2), 113-133. https://doi.org/10.1207/s15327868ms1202_2

Moreh, S. (1976). Modern Arabic Poetry: 1800-1970; the Development of Its Forms and Themes under the 
Influence of Western Literature (Vol. 5). The Netherlands: Brill Archive.

Myers-Scotton, C. (2006). Natural Codeswitching Knocks on the Laboratory Door. Bilingualism: Language and Cognition, 9(2), 203-212. https://doi.org/10.1017/S1366728906002549

Obeng, S. (2002). The Language of Politics. In S. Obeng \& B. Hartford (Eds.), Surviving Through Obliqueness: Language of Politics in Emerging Democracies (pp. 1-18).

Penninck, H. (2014). An Analysis of Metaphor Used in Political Speeches Responding to the Financial Crises of 1929 And 2008. Unpublished doctoral dissertation.

Plett, H. (1991). Intertextuality (Vol. 15). Berlin: Walter de Gruyter.

Reynolds, D. (1995). Repetition in Nonnative Speaker Writing: More than Quantity. Studies in Second Language Acquisition, 17(2), 185-209. https://doi.org/10.1017/S0272263100014157

Roy, O. (1994). The Failure of Political Islam. Massachusetts: Harvard University Press.

Ryding, K. (2005). A Reference Grammar of Modern Standard Arabic. Cambridge: Cambridge University Press. https://doi.org/10.1017/CBO9780511486975

Sanders, L., \& Visona, M. (2012). The Soul of Tahrir: Poetics of a Revolution. Translating Egypt's Revolution. In S. Mehrez (Ed.), The Language of Tahrir. Cairo.

Sauer, C. (1996). Echoes from Abroad-speeches for the Domestic Audience: Queen Beatrix' Address to the Israeli Parliament. Current Issues in Language \& Society, 3(3), 233-267. American University Press in Cairo.

Schaffner, C. (1996). Political Speeches and Discourse Analysis. Current Issues in Language \& Society, 3(3), 201-204.

Shareef, A. A. (2016). Analysing Significant Translated Social and Literary Aspects in Randolph Stow's Merry-Go-Round in the Sea for an Iraqi Audience. Asia Pacific Journal of Contemporary Education and Communication Technology, 2(1).

Sharndama, E. (2015). Political Discourse: A Critical Discourse Analysis of President Muhammadu Buhari's Inaugural Speech. European Journal of English Language and Linguistics Research, 3(3), 12-24.

Shouby, E. (1951). The Influence of the Arabic Language on the Psychology of the Arabs. The Middle East Journal, 284-302.

Shunnaq, A. (1992). Functional Repetition in Arabic Realized Through the Use of Word-Strings with Reference to Arabic-English Translation of Political Discourse. NouveltesDe La Fit-Newsletter, 1(2), 5-39.

Shunnaq, A. (2000). Arabic - English Translation of Political Speeches. Perspectives: Studies in Translatology Journal, 8(3), 207-228. https://doi.org/10.1080/0907676X.2000.9961389

Stepanyan, L. (2015). Stylistic Peculiarities of Political Speeches in English and Armenian. Retrieved November 16, 2015, from http://publications.ysu.am/wpcontent/uploads/2015/12/Lilit_Stepanyan.pdf

Van Dijk, T. A. (1997). What is Political Discourse Analysis? Belgian Journal of Linguistics, 11(1), 11-52. https://doi.org/10.1075/bjl.11.03dij

Van Dijk, T. A. (2006). Discourse and Manipulation. Discourse \& Society, 17(3), 359-383. https://doi.org/10.1177/0957926506060250

Wilson, J. (1990). Politically Speaking the pragmatic Analysis of Political Language. Oxford: Basil Blackwell.

Wodak, R. (2009). The Discourse of Politics in Action: Politics as Usual. UK: Palgrave Macmillan. https://doi.org/10.1057/9780230316539

Woodward, G. C., \& Robert, E. D. Jr. (2014). Persuasion and Influence in American Life. Illinois: Waveland Press.

\section{Copyrights}

Copyright for this article is retained by the author, with first publication rights granted to the journal.

This is an open-access article distributed under the terms and conditions of the Creative Commons Attribution license (http://creativecommons.org/licenses/by/4.0/). 